\title{
The Effect of Training with TQM on the Perceptions of Teachers about the Quality of Schools
}

\author{
Esen Altunay \\ Faculty of Education, Ege University, Turkey
}

Copyright $(\mathrm{C} 2016$ by authors, all rights reserved. Authors agree that this article remains permanently open access under the terms of the Creative Commons Attribution License 4.0 International License.

\begin{abstract}
The purpose of this research is to explore the effect of training with total quality management (TQM) on the perceptions of teachers. In this research was used experimental model. The study group of the research consisted of teachers working in the schools of Education Ministry. The questionnaire was used as a data collection tool. Finally, it was observed that education based on the principles of total quality management was effective to determine the perceptions of the teachers about total quality management practices in their schools. They thought that total quality management practices were inadequate in their schools. Training with TQM might be provided that participants had more realistic assessments of the practices and improvements of quality in their schools.
\end{abstract}

Keywords Total Quality Management, Teacher Training, Postgraduate Students, Management, Quality of Schools

\section{Introduction}

Most people want the best for themselves. Everyone wants the quality of life and this desire is independent of time and situation, because people want to have the best conditions while meeting every need in every period of life such as childhood, adulthood or elderly now and in the past. The level and form of the quality expectation change according to the level of awareness and knowledge of people. Also, people search the quality while they are providing for their requirements at every stage of life. One of these stages that the quality is searched is school life. The school life has great importance for every person and society, because people are educated with knowledge and skills to meet the changing requirements of themselves and society during the school life. The education institutions must realize this duty successfully. In order to the fact that the duties and responsibilities of education institutions can be succeeded it is needed that education process must have high quality $[1,2]$.
A quality education means to be reached to the goals intended and to be carried out these goals by students.

A high-quality education is that education system is approved by society. A high-quality education is that teachers and principals have knowledge and talents following the recentness. Shortly people have these behaviors at the end of education process [3,2]. Therefore, the process of education must be defined, controlled, developed, standardization and adequacy must be provided for quality $[4,5,6,7]$. The quality of education system means providing the quality and richness of human resources, physical sources, students services, social and cultural environment, education technology, the cooperation of education and environment, education administration and curriculum [2,3]. In other words, education system must be raised (heighten) its characteristics and quality as a whole.

Nowadays quality is considering one of the most important subjects by people and institutions [9]. However, the basic of quality is the changing of lifestyle and human behavior. And anything isn't likely to be perfect in a short time. Quality isn't a program to perform in a few months or years, is the philosophy of life, insistence, persistence, to test until success, to learn, knowledge and continuous development $[6,8]$. Education institutions can provide the quality and it must be given great importance to manpower in education institutions. But constructing process according to Taylorism is still continuing in education institutions. Man power has been tried to be educated for future by following behind the producing sector. However for adaptation of current generation of students to information age, they are expected to complete the school period as people who have healthy, creative, tolerant personality, talent of problem-solving, achieving to the knowledge, flexible thinking, making synthesis and analysis, using the technological products, and social [10]. In a quality school students must be given opportunities for searching and investigation, and provided a learning environment in which students gain skills such as expressing hypothesis, inference of result, problem-solving, critical and analytical thinking $[9,11]$. But education institutions cannot adequately succeed 
and students have these skill deficiency.

It should be educated people who continue learning and developing after school life, have a mental structure to sustain the lifelong learning and have a strong motive and will for continuing self-improvement [12]. Hence, it should be required to configure the education culture which provides the total quality management in the education system and all of the workers' active participation in schools and the customers satisfaction $[9,13]$.

\subsection{Theoretical Framework}

Quality is defined differently by many authors. Because quality is varied according to the point of view, is shaped to the requirements and criteria of society $[14,15,16,17]$. On the other hand total quality management (TQM) is the total of management approach, philosophy, organizational structure, and methods. TQM can completely be succeeded with practicing of basic factors which emphasize the human factor and scientism $[2,18]$. TQM is an activity aiming at production process which institutions managers, workers, and students are needed to be aware of problems or failures and decide for the solution [13]. First applications and basic principles of TQM in education institutions were usually focused on improving management processes. However recently principles of TQM have been thought to be able to use effectively in the teaching process and classroom and also to provide important effects on students' successes and attitudes [9]. In this sense in order to implement of TQM in education institutions the top management is obliged to understand the TQM philosophy well, to dedicate and to be a leader of the practices of TQM [12]. Administrators who understand the TQM philosophy, mission and have a visionary point of view can be successful in practice [14]. On the other hand, TQM practices may be unsuccessful due to an inadequacy of substructure, top management, suspicion of workers to TQM practices in schools $[14,19]$.

TQM is an organizational approach which contents many elements from the many organization and management models. TQM involves some aspects of models of scientific management, human relations and structural analysis [20]. Key principles of TQM are customer focus, leadership, continuous improvement, sharing and development of responsibilities, speed response, quality of design, precaution, long-term perspective, management with the facts and cooperation [6,21,22]. The main purpose of TQM is satisfied the customers and tried to improve the quality by determining the customers' quality requirements and providing accurate output. The most important aspect of TQM is that everyone in the system contributes to providing for quality product and service [12]. The first step which this product produces is the classroom in the education system. TQM practices need to be improved in the classes. Therefore doing of research about practices and principles of TQM is of great importance in terms of improvement of the education process, obtaining of the learning products targeted and to be able to construct the successful and effective school.

When the quality of education literature is taken into consideration to be found much research $[2,13,14,23$, $24,25,26]$ which are determined the roles and effectiveness of school management in TQM, level of practicing of TQM and the relationship between TQM performance and success. But it is not seen adequately research that has the experimental method and is tried to raise awareness about TQM. Total quality in education is an approach that is not considered any traditional grading system for students because students are strengthened on improving of personal abilities and capacities. Such the training with TQM is based that all students can learn and be successful to their individual speeds $[9,27]$. As based on TQM teachers should bring the quality works-models to the classrooms and show qualifications and criteria of these models-studies $[9,28]$. The information we learn is expire in few years. Therefore, the product of education must be a person who educates oneself [12]. TQM is of importance in terms of creation of a management structure aiming the complete learning process, supporting self-awareness in classroom management. Training with TQM is a new and an initial attempt to learn about the students' point of view about school innovation and improvement. Therefore, benefits of training with TQM give international results for education and training. In this context, the purpose of this study is to determine the influences of Total Quality Management on the perceptions of teachers about TQM practices in their schools. After the awareness of participants increased, the researcher wanted to determine that the discrimination level on the perceptions of participants (teachers) about the deficiencies of TQM implementations.

\subsection{Research Question and Hypotheses}

The research question is "What is the effect of training with TQM on the perceptions of teachers about TQM practices in their schools?" Accordingly hypotheses of the research are as follows:

H1. The training with TQM affects the perceptions of teachers on the applicability of TQM in their schools between experiment and control groups.

$\mathrm{H} 2$. The training with TQM affects the perceptions of teachers on the applicability of TQM in their schools between measurements (pre test-post test).

H3. Some demographic characteristics of teachers affect the perceptions of them on the applicability of TQM in their schools.

\section{Materials and Methods}

In this research was used experimental research design. In the application of research process was used of Design of Pre test-Post test Control Group (PPCD) design. First, in this research is determined an experimental group. The 
experimental group consisted of teachers and school principals. Also, this group is the postgraduate students. Second, it is determined the control group. The control group consisted of teachers and school principals working in different schools of Education Ministry (EM) in Turkey. Pre-test and post-test were applied to these groups by the researcher. The lecturer applied the principles of TQM in the classroom and controlled group dynamics, consensus building and collaborative styles of decision making. Because Total Quality Management is one of the best means of effectively achieving educational goals and objectives[29].

\subsection{Study Group}

The experimental group of the research consisted of teachers and school principals working in the schools of Education Ministry. Also, these teachers and school principals are postgraduate students in the Master' Degree Program of Education Administration, University of Okan. Purposeful sampling technique was used for selecting the study group of the research. The study group was composed of 27 female and 23 male participants. It was seen that 8 of them had 1-5 years, 11 of them had 6-10 years, 11 of them had 16-20 years and 7 of them had 21 years and more professional seniority. 26 of participants were teacher and 15 of participants were an assistant administrator and 9 of participants were principals. The most of participants' background experiences in their schools were 1-5 years.

\subsection{Procedure}

25 people for the experimental group and 25 people for the control group were selected. Perception Scale (assessment of TQM practicing in their schools) was applied for determining the participants' perception situations before application and after application. While the experimental group took training program based on TQM principals, it wasn't applied any education for the control group.

In this research, the intervention was expected to lead to the hypothesized findings, because the investigation of the participants' professional learning and the organizational development of in-service teacher education with TQM will be contributed to the students achievements in the future. The practices of TQM in the classroom improve self-assessment skill and awareness of people. Hence, someone finds out more personal learning styles [29]. For this reason, procedure was applied a long three weeks.

The experimental group was determined from participants working as a teachers or school principals in the schools of Education Ministry and continued to the postgraduate education program and had Total Quality Management (TQM) lesson. The control group was determined from working teachers and also they worked together with the teachers of the experimental group in the same schools. First data were collected before teachers began the course. In the experimental procedure teachers' expectations were the basis of the course. Teachers were motivated in the direction of targets. Teachers were encouraged for active participation to the course and directed to learning with collaborative work. Academic achievements were evaluated. The problem-solving techniques and the brainstorming technique were used. Participants were directed to provide to match with practice in their schools. In throughout lessons the participation of all participants was given importance.

\subsection{Data Collection Tool}

The questionnaire developed by Aydın and Şentürk (2007) was used as a data collection tool in this research. The questions of questionnaire based on the principles of TQM were collected in three dimensions: the management structure of school, the management of human resources and leadership, and cultural structure of the school. The roles of these dimensions by Likert-type scale with four grading were defined as "Completely Agree (4), Partially Agree (3), Least Agree (2) and Strongly Disagree (1).

\section{Results}

\subsection{The Effect of Training with TQM on the Teachers' Perceptions}

Firstly the perceptions of the experimental and control group about the applicability of TQM principles in schools were measured. For this purpose the results of Mann-Whitney $U$ test determining the significance of the different between pre-test scores about the perceptions of experimental and control groups are showed in Table 1

Table 1. T-test results about pre-test scores of experimental and control group

\begin{tabular}{ccccccc}
\hline Groups & $\mathrm{n}$ & Erank & Xrank & $\mathrm{U}$ & $\mathrm{Z}$ & $\mathrm{p}$ \\
\hline Experimental & 25 & 626.50 & 25.06 & & & \\
Control & 25 & 648.50 & 25.94 & 301.50 & -.214 & .831 \\
Total & 50 & & & & & \\
\hline
\end{tabular}

When Table 1 was analyzed, it was observed that the mean of the experimental group was 25.05 and the mean of the control group was 25.94. To see to the effect of training with Total Quality Management to the perception on the applicability of TQM calculated the result of Mann-Whitney $\mathrm{U}$ test. Mann-Whitney $\mathrm{U}$ test was found that it was not statistically significant between pre-test scores about the perceptions of experimental and control groups. The pre-test result showed that the awareness of two groups could low about TQM practices, readiness level or the cognitive entry behaviors of participants could low. This situation showed that before application the perceptions of experimental and control groups were close to each other.

After the experiment, the levels of success of groups and the difference between the groups were measured. For this purpose, the results of Mann-Whitney U test determining the 
significance of the different between post-test scores about the perceptions of experimental and control groups are showed in Table 2.

Table 2. T-test results about post-test scores of experimental and control group

\begin{tabular}{ccccccc}
\hline Groups & $\mathrm{n}$ & $\sum \mathrm{rank}$ & Xrank & $\mathrm{U}$ & $\mathrm{Z}$ & $\mathrm{P}$ \\
\hline Experimental & 25 & 460.00 & 18.40 & & & \\
Control & 25 & 815.00 & 32.60 & 135.00 & -3.45 & .001 \\
Total & 50 & & & & & \\
\hline
\end{tabular}

When Table 2 was analyzed, it was observed that the mean of the experimental group was 18.40 and the mean of the control group was 32.60. To see to the effect of training with Total Quality Management to the perception on the applicability of TQM calculated the result of Mann-Whitney $\mathrm{U}$ test. Mann-Whitney $\mathrm{U}$ test was found that it was statistically significant between post-test scores about the perceptions of experimental and control groups. The result of this post-test showed that the level of perception of the experimental group was less than the control group. Training with Total Quality Management affected the perceptions of experimental group and they evaluated to be lower than control group the TQM practices and efforts in their schools according to TQM principles learned. Consequently, Hypothesis 1 "Training with Total Quality Management affects the teachers' perceptions on the applicability of TQM in their schools between groups." was empirically justified.

\subsection{The effect of Training with TQM on the Teachers' Perceptions between Measurements}

In order to determine the different between mean scores of pre-test and post-test of the scale of perceptions of TQM principles of control group performed the results of Wilcoxon signed rank test were seen in Table 3.
Table 3. The results of Wilcoxon Signed Rank Test about the pre-test and post-test of control group

\begin{tabular}{ccccccc}
\hline $\begin{array}{c}\text { Control } \\
\text { group }\end{array}$ & Ranks & $\mathrm{N}$ & Erank & Xrank & $\mathrm{Z}$ & $\mathrm{p}$ \\
\hline Pre-test & $\begin{array}{c}\text { Positive } \\
\text { rank }\end{array}$ & 13 & 134.50 & 10.35 & & \\
Post-test & $\begin{array}{c}\text { Negative } \\
\text { rank }\end{array}$ & 12 & 190.50 & 15.88 & -.754 & .451 \\
\multicolumn{2}{c}{ Total } & 25 & & & & \\
\hline
\end{tabular}

According to Table 3, control group's pre-test and post-test mean scores were calculated with Wilcoxon signed rank test. The difference between the pre-test and post-test mean scores of the control group were determined that there was statistically not significant. Post-test scores of the perceptions of participants in the control group about the applicability of TQM principles partially increased. This difference of group may be due to remembering the pre-test or to show the trends and efforts protecting their schools. Consequently, Hypothesis 2 "Training with Total Quality Management affects the teachers' perceptions on the applicability of TQM in their schools between measurements (pre test-post test)." was empirically justified.

In order to determine the different between mean scores of pre-test and post-test of the scale of perceptions of TQM principles of the experimental group performed the results of Wilcoxon signed rank test were seen in Table 4.

According to Table 4, experimental group's pre-test and post-test mean scores were calculated with Wilcoxon signed rank test. The difference between the pre-test and post-test mean scores of the control group were determined that there was statistically significant. According to Cohen's $d(T=3,75$, $\mathrm{z}=-4.171, \mathrm{p}=0.00, \mathrm{r}=0,83)$ effect size is large level $(0.75<\mathrm{r}<$ 1.10). Post-test scores of the perceptions of participants in the experimental group about the applicability of TQM principles decreased. This difference of group may be due to training about TQM principles. Because during the postgraduate course, participants (teachers) who had experience of TQM practices may be aware of the deficiencies of TQM practices in their schools and they may have seen inadequately the TQM practices.

Table 4. The results of Wilcoxon Signed Rank Test about the pre-test and post-test of experimental group

\begin{tabular}{ccccccc}
\hline Experimental group & Ranks & $\mathrm{n}$ & Srank & Xrank & Z & P \\
\cline { 1 - 5 } Pre-test & Positive rank & 23 & 7.50 & 3.75 & & \\
\cline { 1 - 5 } Post-test & Negative rank & 2 & 317.50 & 13.80 & -4.171 & .000 \\
\hline Total & & 25 & & & \\
\hline
\end{tabular}

\subsection{Demographic Characteristics and Teachers' Perceptions}

According to some variables such as position, gender, professional seniority and background experiences participant' results about perceptions of applicability of TQM principles were investigated. In order to determine the effect of position (task type) on the scores of post-test was performed Kruskal-Wallis H test. The results were seen in Table 5. 
Table 5. The effect of position of experimental group on the post-test scores about TQM principles

\begin{tabular}{|c|c|c|c|c|c|c|}
\hline Perceptions of TQM & Task type (position) & $\mathrm{n}$ & $X_{\text {rank }}$ & $\mathrm{X}^{2}$ & $\mathrm{Sd}$ & $\mathrm{p}$ \\
\hline \multirow{3}{*}{ Management structure } & Teacher & 11 & 9.27 & \multirow{3}{*}{11.104} & \multirow{3}{*}{2} & \multirow{3}{*}{.004} \\
\hline & Assist.principal & 8 & 12.00 & & & \\
\hline & Principal & 6 & 21.17 & & & \\
\hline \multirow{3}{*}{ Human resource } & Teacher & 11 & 9.14 & \multirow{3}{*}{5.993} & \multirow{3}{*}{2} & \multirow{3}{*}{.050} \\
\hline & Assist.principal & 8 & 15.00 & & & \\
\hline & Principal & 6 & 17.42 & & & \\
\hline \multirow{3}{*}{ Cultural structure } & Teacher & 11 & 9.82 & \multirow{3}{*}{3.929} & \multirow{3}{*}{2} & \multirow{3}{*}{.140} \\
\hline & Assist.principal & 8 & 15.06 & & & \\
\hline & Principal & 6 & 16.08 & & & \\
\hline \multirow{3}{*}{ Perceptions of TQM } & Teacher & 11 & 8.91 & \multirow{3}{*}{7.224} & \multirow{3}{*}{2} & \multirow{3}{*}{.027} \\
\hline & Assist.principal & 8 & 14.44 & & & \\
\hline & Principal & 6 & 18.58 & & & \\
\hline Total & & 25 & & & & \\
\hline
\end{tabular}

When Table 5 is analyzed, according to position the result of Kruskal-Wallis $\mathrm{H}$ test was determined a significant difference on the applicability of TQM principles. Accordingly when was considered the position of participants the perceptions of the participants about the applicability of TQM principles were low in the dimensions of management structure and human resources but there was no significant in the cultural dimension. In order to determine the influence of background experiences in their schools on the scores of post-test was performed the results of Kruskal-Wallis H test were seen in Table 6.

Table 6. The effect of background experiences in their schools of experimental group on the post-test scores about TQM principles

\begin{tabular}{|c|c|c|c|c|c|c|}
\hline Perceptions of TQM & $\begin{array}{l}\text { Professional } \\
\text { Experiences }\end{array}$ & $\mathrm{N}$ & Xrank & $X^{2}$ & $\mathrm{Sd}$ & $\mathrm{p}$ \\
\hline \multirow{3}{*}{ Management structure } & 1-5 Years & 17 & 14.68 & \multirow{3}{*}{3.579} & \multirow{3}{*}{2} & \multirow{3}{*}{.167} \\
\hline & 6-10 Years & 3 & 12.00 & & & \\
\hline & 11-15 Years & 5 & 7.90 & & & \\
\hline \multirow{3}{*}{ Human resource } & $1-5$ Years & 17 & 15.41 & \multirow{3}{*}{6.206} & \multirow{3}{*}{2} & \multirow{3}{*}{.045} \\
\hline & 6-10 Years & 3 & 9.67 & & & \\
\hline & 11-15 Years & 5 & 6.80 & & & \\
\hline \multirow{3}{*}{ Cultural structure } & $1-5$ Years & 17 & 15.56 & \multirow{3}{*}{7.305} & \multirow{3}{*}{2} & \multirow{3}{*}{.026} \\
\hline & 6-10 Years & 3 & 10.00 & & & \\
\hline & 11-15 Years & 5 & 6.10 & & & \\
\hline \multirow{3}{*}{ Perceptions of TQM } & 1-5 Years & 17 & 15.71 & \multirow{3}{*}{7.522} & \multirow{3}{*}{2} & \multirow{3}{*}{.023} \\
\hline & 6-10 Years & 3 & 9.00 & & & \\
\hline & 11-15 Years & 5 & 6.20 & & & \\
\hline Total & & 25 & & & & \\
\hline
\end{tabular}

Table 7. The effect of gender of experimental group on the post-test scores about TQM principles

\begin{tabular}{|c|c|c|c|c|c|c|c|}
\hline Perceptions of TQM & Gender & $\mathrm{n}$ & $\sum$ rank & $\mathrm{X}$ rank & $\mathrm{U}$ & $\mathrm{z}$ & $\mathrm{p}$ \\
\hline \multirow{2}{*}{ Management structure } & Female & 11 & 87.50 & 7.95 & \multirow{2}{*}{21.50} & \multirow{2}{*}{-3.146} & \multirow{2}{*}{.003} \\
\hline & Male & 14 & 237.50 & 16.96 & & & \\
\hline \multirow{2}{*}{ Human resource } & Female & 11 & 90.50 & 8.23 & \multirow{2}{*}{24.50} & \multirow{2}{*}{-2.926} & \multirow{2}{*}{.001} \\
\hline & Male & 14 & 234.50 & 16.75 & & & \\
\hline \multirow{2}{*}{ Cultural structure } & Female & 11 & 94.50 & 8.59 & \multirow{2}{*}{28.50} & \multirow{2}{*}{-2.722} & \multirow{2}{*}{.003} \\
\hline & Male & 14 & 230.50 & 16.46 & & & \\
\hline \multirow{3}{*}{ Perceptions of TQM } & Female & 11 & 90.50 & 8.23 & \multirow{3}{*}{24.50} & \multirow{3}{*}{-2.887} & \multirow{3}{*}{.006} \\
\hline & Male & 14 & 234.50 & 16.75 & & & \\
\hline & Total & 25 & & & & & \\
\hline
\end{tabular}

When Table 6 is analyzed, according to background experiences in their schools the result of Kruskal-Wallis $\mathrm{H}$ test was determined a significant difference on the applicability of TQM principles. Accordingly when was considered the background experiences in their schools the perceptions of the participants who had 11-15 years about the applicability of TQM principles were less than 1-5 years and 6-10 years group in the dimensions of the cultural structure and human resources. But there was no significant in the dimension of the management structure. Participants (teachers) who had long background experiences in their schools thought negatively more than the others about the using of human resources and cultural structure according to TQM.

In order to determine the influence of gender on the scores of post-test was performed the result of Mann-Whitney U test were seen in Table 7.

When Table 7 is analyzed, according to gender the result 
of Mann Whitney-U test was determined a significant difference on the applicability of TQM principles. Accordingly when was considered gender the perceptions of the participants who were male about the applicability of TQM principles were higher than female in all dimensions. Participants who were male adequately perceived the TQM practices in their schools but who were female inadequately perceived the TQM practices.

In order to determine the influence of professional seniority on the scores of post-test was performed the result of Kruskal-Wallis $\mathrm{H}$ test. According to professional seniority the result of Kruskal-Wallis $\mathrm{H}$ test was determined no significant difference on the applicability of TQM principles. Accordingly when was considered professional seniority the perceptions of the participants were showed similar features. As a variable professional seniority of participants, teachers may not influence their perceptions of the TQM practices in their schools. Consequently, Hypothesis 3 "Some demographic characteristics of teachers affect the perceptions of teachers on the applicability of TQM in their schools" was empirically justified.

\section{Discussion and Conclusion}

According to our results, the difference between experimental group and control group's pre-test scores were no significant. That is to say, in the beginning, their views were similar to TQM practices in their schools. But after the course, the experimental group's opinions were negative. Training with Total Quality Management affected participants perceptions and participants evaluated to be lower the suitability of practices in their schools on the principles of TQM. According to the literature were determined teachers perceived to be effective the TQM in their schools [14]. Aydın and Şentürk [30] were determined that TQM can substantially be applied in primary schools. In the research of Okay [31] the effects of TQM practices in the secondary schools to the communication of stakeholders were found at the medium level [14]. In another research results, school principals reported a positive opinion regarding the applicability of TQM in the secondary schools [2]. Teachers worked in the TQM teams had positive opinions more than teachers that did not work in the TQM teams about TQM practices which provide positive contributions to communication between teachers and students' families [31]. Özdemir [9] reported that teaching based on the principles of TQM is more effective in increasing on the students' attitudes and achievements than other instruction techniques. In addition Kocabaş [32] concluded that the success of students in the English lesson increased with using of the principles of TQM. Esirtgen [33] reported that in the some of the private educational institutions the success of students increased by the teaching activities considering the principles of TQM. According to the results of this study and the literature in the education institutions the level of awareness about TQM principles was low. The reason of the result was low the level of readiness or basic knowledge level. After the experiment, the levels of perception of the control group showed to a partial increase because they were likely to remember the pre-test or have protection efforts of their schools. However, the perceptions of the experimental group about the applicability of the principles of TQM were affected negatively. Although the awareness of experimental may have been developed, they may have increased their expectations and seen inadequately current practices. Training with TQM provides to face with practices of TQM for participating teachers. In this context, this study presents preliminary results for educational management researchers on the international educational literature.

In this research according to the influences of positions (task type), background experiences in the school and gender of participants the perceptions of participants about the applicability of the principles of TQM were found to be a significant difference. Accordingly among the participants who were female, teachers and long background experience evaluated inadequately more than male, principals and short background experience in the school the level of TQM practices. It was found no significant difference between professional seniority of and evaluation based the principles of TQM of participants. According to the literature perceptions of female teachers working in the elementary schools about TQM and the dimension of leadership in improving quality were found to be more positive than male teachers. This result has connected this situation with the result that commitment of women to organizations was higher level more than men [34, 35]. Another research results were as follows, teachers employed 6-10 years were lower satisfaction levels than other teachers in the evaluation of the influence of TQM practices in the schools on the communication between stakeholders. Views of teachers employed 11-15 years were more positive than teachers employed 6-10 years about the communication between stakeholders of school by TQM practices [31]. In the research of Açıkyürek [6] was not determined a significant difference according to gender. After TQM practices in the classroom students' attitudes were seen similar in terms of the levels of change for male and female students. Aksu [14] found that teachers' perceptions about TQM were higher than moderate level. Teachers' perceptions about TQM showed a significant difference in terms of gender, the number of students in their school, provinces served and school served that received and did not receive TQM awards. But teachers' perception didn't show a significant difference in terms of professional seniority, branches, and education levels. Our results clearly show that when awareness of female participants increased also their expectations increased. Some participants who were school principals had continued to think positively about TQM activities in their school although teachers had though negative, because school principals may have an incorrect or protectionist perception about their schools. Perceptions of new participants who started to work in the school were more 
positive than teachers working a long time about TQM in their schools. This result may indicate that participants (teachers) considered more objective after they recognized their corporate culture and time passed and they may see problems.

Finally, it was observed that the training based on the principles of TQM was effective to determine the perceptions of the participants (the teachers and school principals). That is to say, TQM training provided that participants had a more realistic assessment about the practices of improvements of quality in their schools. Increasing of participants' professional learning with TQM training, they experienced TQM practices and understand their schools dynamics. Therefore educational researchers should be concerned with the issue of teachers' perceptions of the utility of TQM. If the teachers' perceptions of the utility of the TQM in the schools are positive, education and schools will be improved.

\section{Limitations of the Research \& Future Studies}

One limitation of this research was the small sample size. Future research might expand the sample size. In addition this research performed a long three week, future research might longer while. Another limitation was the fact that the evaluation of the course was made in one-course group of teachers. Comparisons with the other group might reveal some differences between the outcomes in the two groups. Finally, although this study is important for determining of the change of perceptions of teachers (participants) regarding TQM, in-service training and master degree program should be done to improve their awareness and these should be continuous. In the programs of institutions of teacher training should be added an elective course (lesson) comprising the implementation the principles of TQM in the classroom. With this elective course, teacher candidates can contribute that their students learn more qualified form through applying the principles of TQM in the teaching process with.

\section{REFERENCES}

[1] İ. H. Taş, The contributions of theory of total quality management to the education management. The Journal of National Education, Vol: 145,76-80, 2000.

[2] İ.F. Yenel, T. Çolakoğlu, İ. Demir, A study on the administrators' opinions about applicability of TQM in the secondary schools). The Journal of Niğde University Physical Education and Sport Science, Vol:2, 111-120.2008.

[3] A. Temel. Total quality management in education. The Journal of National Education, 44, 48-50. 1999

[4] S. Özdemir, Efficiency in education and total quality management. The Journal of Educational Administration, Vol: 3, 421-426. 1996.

[5] W. E. Deming, Out of The Crisis (rev. ed.). Cambridge, MA: MIT Press. 2000.

[6] Ö.Aç1kyürek, The Effect of Applications of TQM in Course of Mathematics on the Students' Academic Achievements and Attitudes Against Course. Master Degree Thesis. Yedi Tepe University Social Science Institute. Education Administration and Supervision Program. İstanbul. 2007.

[7] H. Şimşek, Total Quality Management: Theory Principles and Practices. First Edition. Seçkin Published, Ankara. 2010.

[8] S. Özbaşar, Key of winning in the tourism industry: total quality management. The Journal of Ago Quality, Vol:11, 8-12. 1995.

[9] S. M. Özdemir. In teaching processes the impact of the implementation of the principles of total quality to the students' attitudes and achievements. The Journal of Kastamonu Education, Vol:15, No: 2, 521-536. 2007.

[10] G. Hergüner. Benefits to provide of the total quality practice in education). The Journal of Educational Administration, Vol: 4, No: 13, 1-21. 1998

[11] E. D. C. Lachlan, P. Shutler. Total quality management in education: problems and issues for the classroom teacher. The International Journal of Educational Management, 13 (2), 67-72.1999.

[12] G. Yıldız, K.Ardıç, Total quality management in education). The Journal of Information, Vol: 1, 73-82. 1999.

[13] J. Dahlgaard, K. Kristensen, K. C. Kanji, Total quality management and education. Total Quality Management, 6, 5-6. 1995.

[14] A. Aksu, TQM and visioner leadership in primary schools. Education and Science, Vol: 34, No:153, 99-116. 2009.

[15] Y. Özden, The Transformation In Education, Pegem Published, Ankara. 1999.

[16] Z. Muluk, E. Burcu, N. Danacioğlu. The Development of Quality Case in the Turkey (1299-1990). Kal Der Published. Ankara. 2000.

[17] J. Juran. Juran on Planning for Quality. Free Pres, New York, USA. 1988.

[18] İ. Günbay1, V. Çevik. A research about the opinions of administrators and teachers on the total quality management. The Journal of National Education, Vol:163, 32-34. 2004.

[19] H. Ensari, Total quality management for the 21st century schools. Sistem Published İstanbul. 1999.

[20] M. F. Guillen. New trends in management and evolution of organizational models. (Translation: Murat ÖNDER), The Journal of Productivity, Vol: 25,No:4, 7-20. 1996.

[21] R. M. Hodgets, Implementing TQM in small and medium size organization. Association Press. USA. 1996.

[22] M. Terziovski, D. Samson. The link between total quality management practice and organizational performance. International Journal of Quality and Reliability Management, Vol: 16, No: 3, 226-237. 1999.

[23] L. E. D. Crawford, P.Shutler. Total Quality Management in 
education: problems and issues for the classroom teacher. The International Journal of Educational Management, Vol: 13, No:2, 67-72. 1999

[24] R. Kaufman. The challenge of total quality management in education." International Journal of Education Reform, Vol:1, No: 2, 149-65. 1992

[25] S. Vlašić, S. Vale, D. K. Puhar. Quality management in education." Interdisciplinary Management Research, Vol: 5, 563-575.2009.

[26] W. E. Deming. Foundation for management of quality in the western world. Paper delivered in Osaka, Japan, 1989; revised 1991. Reprinted in An Introduction to Total Quality for Schools: A Collection of Articles on the Concepts of Total Quality Management and W. Edwards Deming, edited by the American Association of School Administrators. Va.: AASA, Arlington,. 1991

[27] M. A, Byrnes, R. A., Cornesky, L. W. Byrnes, The Quality Teacher: Implementing Total Quality Management In The Classroom. Cornesky and Associates Press. 1993.

[28] C. D. Glickman. Leadership for Learning. Association For Supervision And Curriculum Development. Alexandria, Virginia. 2002.

[29] R. R. Sims, S. J. Sims. The Importance of Learning styles.
Greenwood Publishing Group, United States of America, Inc. 1995.

[30] A. Aydın, İ. Şentürk. The Practices of TQM in Education: The Sample of Primary Schools. The Journal of Social Sciences, Vol:7, 1-19. 2007.

[31] Ş. Okay. Effects of total quality management applications to the communication between partners at vocational and technical secondary education. The Journal of TÜBAV Science, Vol:1, No:2, 79-87. 2008.

[32] E. Kocabaş. Effect of total quality management approach to English lesson success in primary education and a research. The master degree thesis. Marmara University, The Institute of Educational Sciences. İstanbul. . 2005.

[33] B. Esirtgen. Applicability of total quality management philosophy in the education sector. the master degree thesis. Uludağ University, Social Sciences Institute, Bursa. 2005.

[34] R. Balay. Organizational commitment of administrators and teachers in the private and public high schools: the case of province of Ankara. Doctoral thesis. Ankara University. Social Sciences Institute. Ankara. 2000.

[35] Y. F. Taş, A.Aksu. Total quality management and strategic leadership. The Journal of Organization and Administration Sciences. Vol: 3. No: 2, 351-361. 2011. 